\title{
A elite em festa: a comemoração do Carnaval de Pelotas na década de 1910
}

\author{
The Elite in party: the celebration of \\ Pelotas Carnival in decade of 1910
}

Alvaro Barreto*

Resumo: O artigo busca caracterizar os diferentes modos de comemorar o Carnaval, promovido pela elite da cidade de Pelotas, nos anos 1910. Para isso, promove um inventário dessas práticas, procura relacioná-las às que eram realizadas em outras cidades, em especial o Rio de Janeiro, bem como às análises de historiadores e cientistas sociais.

Palavras-chave: Carnaval, Elite, Pelotas, Década 1910

Abstract: This paper aims to describe the different ways of celebrating Carnival, sponsored by the elite of Pelotas city in the years 1910. For this, it promotes an inventory of such practices and seeks to relate them to what have been held in others cities, especially Rio de Janeiro, as well as the analysis of historian and social scientists.

Keywords: Carnaval, Elite, Pelotas, Decade 1910

\section{Introdução}

Na década de 1910, a cidade de Pelotas possuía aproximadamente 45 mil habitantes ${ }^{1}$, era a segunda mais populosa do Rio Grande do Sul, atrás apenas da capital, Porto Alegre. Reconhecida por suas atividades recreativas e culturais (Magalhães, 1993; Loner, 2002; Müller,

* Professor do Instituto de Sociologia e Política da Universidade Federal de Pelotas. Doutor em História (PUCRS). E-mail: <albarret.sul@terra.com.br>.

1 O município atingia 82 mil pessoas (FEE, 1986). As informações referem-se ao Censo de 1920, pois ele não foi realizado em 1910. 
2010), naquele período ela oferecia um tipo de folia no qual se destacava o "Grande Carnaval" (Queiroz, 1992), um festejo inspirado nas cidades de Veneza, Nice e Paris, promovido pela elite urbana, a partir de seu próprio imaginário, no qual apenas ela podia preponderar. ${ }^{2}$

A distinção entre as classes se expressava pela construção de espaços inacessíveis aos demais, como baile de salão, préstito e corso. Nesse sentido, para participar ativamente da festa, eram necessários significativos recursos econômicos e inserção em determinados grupos sociais, com vistas a: associar-se ao clube, adquirir a fantasia; ser proprietário ou poder alugar carro ou automóvel.

Isso não significava a ausência de comemorações populares na folia, no entanto, o modelo europeizado predominava no centro da cidade e na cobertura da imprensa e, dele, os mais pobres estavam excluídos, ao menos como atores de destaque. Restava, então, o papel de assistência, o qual era desenvolvido com entusiasmo, pois havia um grande público ávido por ver a elite se exibir.

Em todos esses aspectos, o "Grande Carnaval" chocava-se com o Entrudo, a forma de comemoração ainda existente. Embora Ferreira (2005) argumente que a denominação seja genérica, pois abrange brincadeiras muito diferentes entre si, cujo ponto em comum reside no fato de não estarem incluídas no modelo "requintado" imaginado pela elite, a base de tal comemoração reside no fato de as pessoas jogarem umas nas outras: líquidos (água, perfume e outros não tão recomendados), ovos, lama e diversos tipos de pós, em especial farinha. Essa característica fazia com que qualquer um pudesse participar do Entrudo e ele fosse comemorado em qualquer lugar. ${ }^{3}$

A diferença entre ambos e o fato de o Entrudo ser a festa estabelecida, fez com que ele fosse duramente combatido pelas sociedades carnavalescas e pela imprensa, que o tacharam de: bárbaro e

\footnotetext{
Tanto no caso das elites brasileiras quanto no das europeias, o conjunto de festejos que o configuravam resultou de escolhas deliberadas, as quais implicaram construir tradições, selecionar alguns costumes, desconsiderar ou marginalizar outros. Nesse sentido, a festa que as inspirou foi construída e/ou inventada. Ver: Ferreira (2005).

3 Apesar disso, também era marcado por distinções sociais, que se expressavam especialmente nas regras relativas a quem poderia molhar quem, como mostram Queiroz (1992), Araújo (1996), Flores (1999) e Araújo (2008), e nos utensílios utilizados. Aos limões de cheiro, somavam-se: recipientes caseiros (canecas, baldes, jarros e bacias) e artefatos surgidos ao longo do século XIX, produzidos especialmente para a comemoração e que compreendiam preços variados (sifões, bisnagas e seringas). Lazzari (2001, p. 124-125) mostra como, em Porto Alegre dos anos 1870, a introdução de bisnagas importadas da França trouxe dificuldade para que alguns pudessem fazer frente à nova moda.
} 
pouco refinado, desregrado, perigoso à saúde, inapropriado para cidades em processo de modernização. ${ }^{4}$

Porém, nos anos 10, o "Grande Carnaval" já dava sinais de cansaço no Rio de Janeiro, o principal centro irradiador deste modelo (Eneida, 1958; Queiroz, 1992; Cunha, 2001). No mesmo período, em Pelotas, ele atingia um patamar sem medida de comparação com o que apresentara até então, principalmente graças à rivalidade entre dois clubes carnavalescos 5 : Diamantinos, fundado em 1906, e Brilhante, criado cinco anos depois. ${ }^{6}$ A denominação dessas entidades não deixa dúvidas sobre a qualidade de seus componentes, afirmados como jóias de alto valor, reflexo de suas posições na hierarquia social.

Com vistas a caracterizar a folia pelotense dos anos 1910, o texto apresenta os principais festejos realizados pela elite e, sempre que possível, relaciona-os com as formas de comemoração promovidas em outras cidades, em especial o Rio de Janeiro, e com as análises de historiadores e cientistas sociais.

\section{Préstito}

O ponto alto da atividade dos clubes residia no préstito, o desfile de carros alegóricos pelas ruas da cidade, evento que buscava mostrar luxo, refinamento e arte, com vistas a deslumbrar a plateia. ${ }^{7} \mathrm{O}$ padrão era a realização de dois passeios: um durante o tríduo momesco, outro durante a Pinhata. ${ }^{8}$ O Diamantinos veio a público nos anos de 1907 a 1918 e em 1920. Já o Brilhante, de 1912 a 1920, com exceção de $1918 .{ }^{9}$

Embora não houvesse um itinerário rigidamente definido, o desfile compreendia: partida da caverna ${ }^{10}$ e a passagem por diversas ruas do

4 Sobre as críticas, ver: Cunha (2001), Lazzari (2001), Pereira (2004), Ferreira (2006).

5 A expressão identifica entidades que afirmavam a intenção de comemorar os Dias Gordos, especialmente por meio do préstito. Isso não as impedia de desenvolver atividades recreativas não especificamente carnavalescas.

6 As duas entidades, já centenárias, continuam ativas, agora como clubes sociais. Nessa condição, promovem festas e possuem infraestrutura para atividades de lazer e de esportes.

7 No carnaval pelotense, eles não eram novidade, pois vinham sendo apresentados desde a década de 1870, embora não de modo contínuo.

8 O final de semana posterior ao Carnaval, o que em outras localidades é chamado de "Enterro dos Ossos".

9 Eles também desfilaram ocasionalmente ao longo dos anos 1920-1930, período em que surgiram outros dois clubes que apresentaram carros alegóricos (Fantoches e Atrasados), mas que não resistiram muito tempo.

${ }^{10}$ Local onde os carros alegóricos eram construídos. Originalmente, era o apelido da sede da sociedade carnavalesca carioca Tenentes do Diabo. 
centro, sem faltar jamais a rua Quinze de Novembro, entre a rua Gal. Neto e a praça Coronel Pedro Osório. Deve-se destacar que tal trecho, bem como o entorno da praça, era o espaço por excelência do carnaval pelotense até o início dos anos $1980 .{ }^{11}$

O préstito era aberto por uma banda de clarins a cavalo, seguindose os carros alegóricos, a começar pelo do Porta-Estandarte. Alguns possuíam guarda de honra, em especial o da Rainha. Fechavam o cortejo: o zabumba ${ }^{12}$ e decorados veículos de tração animal (depois substituídos por automóveis de capota descoberta) que transportavam diretores, associados e simpatizantes. As bandas ficavam entre algumas das alegorias para garantir que sempre houvesse acompanhamento musical. ${ }^{13}$

Montados sobre estrados cedidos pela companhia ferroviária, os carros eram puxados por parelhas de cavalos ou bois enfeitados, conduzidas por guarda fantasiada, composta por negros. ${ }^{14}$ Eles cumpriam o trajeto em velocidade reduzida tanto pela dificuldade de movimentação motivada pelo excesso de público e de peso quanto para facilitar a observação. Por esses motivos - aos quais se podem acrescentar as paradas para declamação de poemas, apresentação de discursos e oferecimento de homenagens -, o préstito tinha longa duração.

$\mathrm{O}$ desfile ocorria à noite, mas a concentração começava em torno das $15 \mathrm{~h}$, pois o processo de retirada dos carros da caverna e colocação dos figurantes não era fácil, ainda mais quando o clube não tinha nenhuma obrigação formal a cumprir. Não havia coordenação entre as entidades para formular regras comuns em relação aos cortejos e tampouco ação do poder público com vistas a definir o dia e a duração do passeio, a ordem de saída das entidades e o roteiro a ser percorrido. ${ }^{15}$ Igualmente, inexistia concurso oficial.

${ }^{11}$ Desde então os desfiles têm sido realizados em diversos pontos da cidade, sem que se estabeleça um local definitivo.

${ }^{12}$ No caso do préstito, tratava-se de um carro alegórico mais simples em comparação aos demais, que trazia rapazes fantasiados que tocavam instrumentos de percussão.

${ }^{13}$ Cunha (2001) destaca que as sociedades cariocas desfilavam ao som de trechos de ópera. Em Pelotas, não foi possível encontrar referências definitivas sobre a trilha sonora que acompanhava os clubes.

${ }^{14}$ Os negros também participavam do préstito como músicos das bandas contratadas pelos clubes.

${ }^{15}$ A intervenção do governo municipal ficava restrita a: oferecimento de uma pequena subvenção, limpeza e reparo do calçamento das vias em que passaria o préstito. Não se incluem nesta questão as atividades de manutenção da ordem pública que eram reforçadas durante a festa. 
Diversas vezes a imprensa reclamou da demora dos préstitos que, em alguns anos, só apareceram à rua Quinze de Novembro após às $23 \mathrm{~h}$. A ausência de coordenação também gerava situações potencialmente conflituosas: em 1915, os carros vinham em sentido contrário na rua Quinze de Novembro e fatalmente se encontrariam, o que poderia gerar tumulto e uma série de xingamentos e de agressões físicas. Diante do quadro, o Diamantinos retardou a chegada à esquina, o que possibilitou ao Brilhante dobrar à rua Gal. Neto e evitou o choque entre os carros (Barreto, 2003).

A totalidade do préstito não formava um enredo a ser desenvolvido, pois cada carro era independente dos demais. Apesar disso, eles procuravam cumprir um princípio pedagógico comum: trazer alegorias suntuosas, elaboradas com requinte artístico, marcadas pela elegância, o que mostrava a superioridade cultural de seus promotores e, ao mesmo tempo, trazia erudição ao povo. Desse modo, seria possível preencher as ruas de civilidade e de civilização, tudo isso por meio do imperativo da alegria.

Ele representava claramente o universo cultural dos setores burgueses locais. Pode-se sintetizar a temática em: críticas a fatos do cotidiano e a personalidades, principalmente políticas; homenagens a instituições, a entidades de classe ou de esportes, bem como a vultos nacionais, a símbolos da pátria e ao elemento indígena. Os clubes também gostavam de alegorias com motivos clássicos e românticos ou com representações de locais exóticos. Não faltavam, ainda, referências a objetos comuns (cesta de frutas, ramalhete, novelo de lã).

As homenagens formavam quadros mais harmônicos, mas aqueles realmente "orgânicos" eram os de crítica, nos quais os componentes faziam performances e distribuíam poemas satíricos, embora estes não fossem os mais luxuosos. ${ }^{16}$ Assim como ocorria com as sociedades carnavalescas cariocas naquele período, que haviam abandonado os "carros de ideia" tão adotados nos anos 1880, havia mais alegorias que tinham por objetivo render homenagem e representar objetos ou ambientes distantes no tempo e no espaço do que promover críticas (Cunha, 2001; Pereira, 2004).

Os clubes também demonstravam o gosto por inovações tecnológicas, como: novos efeitos de iluminação, uso de diversos tipos de espelhos e, grande destaque, alegorias móveis, que estrearam em

${ }^{16}$ Eles não figuram nos registros dos carros alegóricos. Ou não foram considerados importantes o suficiente para serem fotografados ou tais registros se perderam. 
1913. A iluminação era um dos segredos do sucesso, mas também de preocupações dos organizadores, pois havia risco de as serpentinas provocarem um incêndio.

Os adultos apenas participavam da organização, desfilavam em veículos colocados ao final do desfile ou acompanhavam as alegorias, com vistas a evitar risco para os participantes, em especial quedas ou agressões do público. ${ }^{17}$ Nos carros saíam apenas crianças, adolescentes e homens solteiros (estes, apenas no carro Zabumba), fantasiados ou em trajes requintados e que não expunham os corpos além do que já era aceito em outros ambientes sociais. As vestimentas a serem utilizadas eram pré-definidas, assim como o local que cada um iria ocupar no carro, embora não se saiba quem custeava a confecção da roupa (provavelmente a família do associado). O préstito era familiar e não exaltava o erotismo e a sensualidade, razão pela qual também nesse quesito estavam mais próximos das primeiras grandes sociedades cariocas do que daquelas que atingiram o apogeu nos anos 1880, que se afirmavam como tipicamente masculinas e apresentavam prostitutas com trajes indecentes e em atitudes lascivas (em ambos os casos, para os padrões da época). ${ }^{18}$

Tal comportamento pode se referir aos clubes dos anos 1910, mas não é extensivo ao carnaval pelotense como um todo. Como indica Loner (2002, p. 46), "para a década de [18]90 aparecem referências a carros que percorreram as ruas com 'horizontais', termo galhofeiro usado para referir-se a prostitutas". Situação semelhante ocorria em Porto Alegre: Lazzari (2001) aponta o caráter familiar dos préstitos apresentados por Venezianos e Esmeralda, nos anos 1870-1890, mas registra a presença de uma entidade que incorporou prostitutas no início do século XX.

Todavia, o préstito dos anos 1910 marcou tão fortemente o imaginário pelotense - ao menos o da elite intelectualizada - que Salis Goulart escolheu um dia de carnaval em que Brilhante e Diamantinos desfilaram como a abertura da novela "A Vertigem", publicada em 1925,

\footnotetext{
17 Não foram encontrados casos de agressão, contudo, dois fatos ocorridos em 1917, relatados por Guimarães (2002), revelam a facilidade de acesso ao cortejo. No primeiro, Zilda Maciel, Rainha do Diamantinos, declarou ter passado por um grande susto, quando um homem subiu no carro alegórico. A intenção dele era amistosa (proferiu um discurso e entregou-lhe um presente) e provavelmente já tivesse sido informada aos diretores do clube, o que facilitou a aproximação. No segundo, os populares, entusiasmados com o préstito, mesmo sem o consentimento da diretoria, desatrelaram os cavalos e passaram a puxar o carro da Rainha.

${ }_{18}$ Para mais detalhes, ver: Cunha (2001), Pereira (2002) e Pereira (2004).
} 
considerada por Magalhães (2002, p. 294) a primeira obra de ficção que teve como cenário o meio urbano de Pelotas. $\mathrm{O}$ autor narra:

era já meia-noite e os clubes carnavalescos demoravam a sua entrada triunfal, ao estrídulo das cornetas belicosas e ao compasso dos tambores rolantes. Uma ansiedade de expectativa pairava em todos os corações, no desejo irrequieto de cotejarem o brilho aparatoso dos dois clubes contendores, que dentro em breve entrariam na rua Quinze, movendo as grandes rodas dos carros pelos paralelepípedos do calçamento. Num dado momento, ovações entusiásticas se fizeram ouvir - Viva o Clube Diamantinos! - Viva o Clube Brilhantes! (Goulart, 1925, p. 4-5 apud Idem, p. 291-292).

Na continuidade, Salis Goulart narra o arrefecimento do entusiasmo popular após a passagem dos clubes: "desde que os carros do último clube haviam cruzado a cidade, acentuava-se a deserção dos pontos mais procurados. E agora um contínuo rodar de carruagens, como que fugindo do centro, a povoar de ruídos as ruas desertas".

Esta não é a única obra literária a incluir referência aos préstitos: na novela "Os Fios Telefônicos", de Fernando Melo, escrita em 1948, mas publicada apenas em 1996, duas personagens recordam como se conheceram em meio à folia: “- Tempos bons - disse o velho - Te conheci no corso. Num carnaval...tu era uma moça bonita... A velha riu. - Havia de ser que tu preferiu. - Me lembro dos carros do Diamantinos e do Brilhantes ${ }^{19}$, tu parecia uma rainha empoleirada..." (Melo, 1996, p. 77). O diálogo gira em torno da lembrança de evento dos 1910, quando da juventude das personagens, porém é relevante que o autor tenha escolhido a festa como este registro, que a represente por meio do corso e do préstito, sendo que a mulher havia desfilado em um dos carros alegóricos, indício de um nível mais intenso de engajamento. ${ }^{20}$

\section{Corso}

Outra opção no cardápio carnavalesco incluía participar do corso e da batalha das flores ${ }^{21}$, que nada mais eram do que passeios, por itine-

19 Tanto Goulart quanto Melo grafam "Brilhantes" ao invés de "Brilhante". Ou ambos cometeram o mesmo equívoco ou, o que é mais provável, era o assim que a entidade era chamada pela população, o que é reforçado pelo modo como Melo busca reproduzir a linguagem coloquial.

${ }^{20}$ Sobre a novela, ver: Barreto (2004).

${ }^{21}$ Era promovida pelo comércio da rua em que estava programada, tendo sido inspirada em evento realizado em Nice desde os anos 1870. Mais informações, ver: Ferreira $(2005,2009)$. 
rários pré-definidos, realizados por carros e automóveis decorados, descobertos ou de capota arriada, que conduziam famílias, amigos ou vizinhos, geralmente fantasiados, às vezes mascarados ${ }^{22}$, que jogavam entre si e para a multidão: confetes, serpentinas, jatos de lança-perfume e flores. Tais desfiles ocorriam tradicionalmente no Domingo e na terça-feira gorda, bem como no Domingo da Pinhata, e, conforme Simson (1984, p. 214-215), ao menos para o caso paulistano, havia proteção do Estado para que eles fossem realizados, pois as ruas eram isoladas, os meios de acesso e de dispersão determinados e a velocidade permitida regulamentada.

Em outro trabalho, Simson (1989, p. 29), ao referir-se ao corso do bairro do Brás, em São Paulo, apresenta novos elementos, seguramente extensivos ao caso pelotense: participavam "pessoas de todas as idades, desde crianças até pessoas idosas, mas observava-se uma certa predominância dos elementos jovens, moças e rapazes, pois o corso era uma ótima ocasião para se entabular namoro".

Embora uma parte da historiografia registre que o primeiro corso ocorreu no Rio de Janeiro em 1907 (Eneida, 1958; Valença, 1996), o hábito de passear em veículo decorado durante o carnaval existia há muitas décadas. O que ocorreu em 1907 foi a oficialização, sob uma denominação específica, de uma prática que recentemente havia sido incrementada em função do avanço do automóvel e da inauguração de amplas e modernizadas avenidas.

Uma nota da imprensa pelotense de 1895 indica a existência do costume e, inclusive, o uso do termo antes desse período: "somente podem formar no corso (...) as pessoas que, até às $16 \mathrm{~h}$, prevenirem a comissão" (DIÁRIO POPULAR, 02 mar. 1895, p. 1). Ainda nesse ano foram registrados mais de 50 carros na Batalha das Flores (Idem, 05 mar. 1895 , p. 2). Em 1896, praticamente todos os elementos que configuram o corso já estavam estabelecidos: "muitos carros particulares e de praça, ocupados por famílias e alegres rapazes, faziam constantes voltas pelas ruas centrais" (Ibidem. 18 fev. 1896, p. 1). Já em 1913, a nota permite observar o crescimento do corso (houve a participação de 200 carros, quatro vezes mais do que 18 anos antes) e a transição que a cidade vivia em termos de meios de transporte (40 eram automóveis e os outros 160 diferentes veículos de tração animal) (Ibid. 05 fev. 1913, p. 1).

\footnotetext{
${ }^{22}$ As denominações se prestam a confusão, seja no âmbito do corso, seja em outras atividades carnavalescas, pois o folião podia usar: 1) máscara, acompanhada ou não de fantasia; 2) fantasia, com o rosto descoberto ou não. Neste trabalho, os termos "fantasia" ou "fantasiado" excluem o uso da máscara, embora os termos "máscara" ou "mascarado" possam contemplar o acompanhamento de fantasia.
} 
No entanto, Valença (1996, p. 26) lembra que

a grande maioria dos foliões, não possuindo automóveis - luxo restrito a uns poucos na primeira década do século - não ficaria alijada do corso. Assim, à volta dos carros se formavam fileiras de pessoas que, dançando e cantando as músicas em voga, saudavam as moças fantasiadas, jogando sobre elas flores e confetes.

O confete merece uma especial referência, pois foi um artigo que modificou o modo de celebrar a folia. Em Pelotas, o primeiro registro data de 1895, o que implica atraso em relação a outros centros, caso do Rio de Janeiro, no qual ele chegou em 1892 (Efegê, 1982, p. 86). ${ }^{23} \mathrm{O}$ que o determinou foi a Revolução Federalista (1893-95), período no qual a folia praticamente não foi comemorada nas ruas. Algo semelhante ocorreu em Porto Alegre, que conheceu o artefato em 1896 (Damasceno, 1970, p. 107).

A vantagem do confete residia em: ser versátil (podia ser usado sem restrições em todas as atividades carnavalescas), não ter um custo proibitivo $^{24}$ e representar uma alternativa refinada, civilizada (e seca, obviamente) de praticar as mesmas ações que caracterizavam o Entrudo, tanto que foi chamado de "Entrudo civilizado" (Araujo, 1996, p. 237). Este ainda tinha grande apelo, inclusive entre a elite, pois vários autores registram que, em pleno período de apogeu do "Grande Carnaval", ele continuava a ser praticado pelas famílias em salões de hotéis, bailes ou em suas residências, pois a brincadeira em si era divertida, o que não soava agradável era ficar à mercê de qualquer um ao sair à rua. Ferreira (2005, 2006), por exemplo, distingue duas acepções da "molhadeira" do Entrudo: a "popular" (e perigosa), que ocorria nas ruas, suscetível às mais diversificadas tensões sociais, e a "familiar", inocente e aceitável,

${ }^{23} \mathrm{O}$ artigo teria surgido em Paris nesse mesmo ano. O que há de novo nesse confete é o fato de ele ser de papel cortado em formato circular, por isso bem mais leve, pois, cf. Ferreira (2004, p. 54-55), ele vinha sendo utilizado no Brasil pelo menos desde os anos 1850 sob a forma de pequenos confeitos (daí o seu nome), de grãos ou de gesso que eram jogados nas pessoas, assim como ocorria na Europa. Mas há referência ao uso de "pequenos papéis de diversas cores, cortados em pedaços" ou "microscopicamente" antes de 1892, como em Santos, na folia de 1888 (Bandeira Júnior, 1974, p. 61), e em São Paulo, em 1891 (Simson, 1988, p. 138).

${ }^{24} \mathrm{O}$ confete era vendido por peso e acondicionado em sacos. Havia produtos mais caros e que serviam para reforçar a distinção social, como aqueles inseridos em estojos e os "confetes de fogo", elaborados com pólvora e que os lançavam à grande altura (Cunha, 2001, p. 82). Porém, era possível participar da brincadeira ainda que o folião não tivesse recursos para comprá-lo, bastava apanhar aqueles que estivessem ao chão, prática que recebia a alcunha de "confete do agacha" e não era vista como adequada a indivíduos refinados. 
praticada por pessoas que se conheciam e que respeitavam as normas sociais que regulavam o jogo.

Nesse contexto, substituir a água pelo confete era uma forma de manter a essência da brincadeira (atirar coisas nos outros) e atingir um grau de sofisticação adequado ao ideário do "Grande Carnaval", o que se verifica claramente quando ele era usado como meio de corte: o mesmo interesse manifestado via limão de cheiro ou bisnaga, agora ocorria por meio do confete, especialmente durante o corso (Barreto, 2003). Esta não é a posição de Cunha (2001), pois ela enfatiza que, apesar das novas possibilidades que oferecia, o confete guardava mais traços de continuidade com o Entrudo do que de correspondência ao ideário civilizatório do "Grande Carnaval". Nessa perspectiva, Eneida (1958, p. 162) informa que o povo o adotou "se bem que de começo $\mathrm{a}[\mathrm{o}]$ incluísse entre os jogos violentos; confetes enchiam bocas, eram jogados dentro de roupas etc", bem como Araújo (2008, p. 157) registra crônicas da imprensa que clamavam aos foliões o uso elegante, isto é, que o confete não podia servir para agredir os demais, uma comprovação de que, em meio à festa, e apesar das diferenças materiais entre ele e um limão de cera, podia ser utilizado de modo muito semelhante ao que ocorria no Entrudo.

\section{Baile de salão}

Uma das alternativas à disposição do folião pelotense dos anos 1910 era frequentar os bailes de salão, tanto os de máscaras (bal masqué25), quanto os à fantasia, comemorados nos mais prestigiados recintos da cidade (Biblioteca Pública, clubes Caixeiral e Comercial).

Eles não constituíam uma novidade naquela época, pois compunham o elenco da folia há muito tempo - e assim continuam. Embora necessários à festa, que sem os bailes não seria a mesma, nem por isso eram vistos como uma manifestação que pertencesse à essência do carnaval, isso porque não eram realizados nas ruas, o locus por excelência das comemorações. Assim, o "Grande Carnaval" precisava dos bailes de salão, mas se só houvesse tais festejos, faltaria o principal, composto pelo préstito e, em menor medida, pelo corso. Em 1906, por

\footnotetext{
${ }^{25}$ Eram raros nos anos 1910, depois de terem sido muito realizados em décadas anteriores. Cf. Müller (2010, p.170), os primeiros ocorreram em fevereiro de 1853, no Teatro Sete de Abril. A mesma fonte (Idem, p. 200-202) indica que eles também eram promovidos em hotéis e em outros períodos do ano, logo, não eram atividade exclusivamente carnavalesca. Ferreira (2005) aponta a mesma situação no Rio de Janeiro.
} 
exemplo, o Diário Popular (27 fev. 1906, p. 2) anotou que: "Momo não teve comemorações externas, passeatas brilhantes, mas intermuros, foi um dar de pernas como nunca! Dançou-se, ainda dança-se e dançar-se-á futuramente até a Pinhata."

$\mathrm{O}$ evento a que este artigo faz referência era uma festa privada ou particular, restrita a público abastado e que trazia como exigências: apresentar uma roupa adequada (fantasia, máscara ou, simplesmente, uma vestimenta elegante), ser sócio da entidade que a realizava ou, quando isso não era possível, ser digno de um convite. Como destaca Queiroz (1992, p. 130), “os participantes de um baile 'fechado' formam por definição um conjunto homogêneo uma vez que foram previamente escolhidos com essa finalidade; divertem-se num recinto que pode não ter divisões internas e estão verdadeiramente "entre pares".

Conforme Piccoli (1996, p. 17), aquele realizado pelo Diamantinos em 1914 contou com aproximadamente duas mil pessoas, das quais 350 pares tomaram parte na polonaise.$^{26}$ No evento promovido pelo Brilhante em 1917, 233 pares dançaram a primeira polonaise e, às 4h30min, 94 tomaram parte na segunda (Barreto, 1991, p. 45). É importante lembrar que os bailes não contavam com um repertório de músicas propriamente "carnavalescas", já que repetiam os ritmos dançados nas demais festas: polcas, valsas, schottish, mazurkas e havaneiras. ${ }^{27}$ Era comum que os salões fossem tomados por grupos com fantasia padrão, os blocos de salão, aos quais será feita referência mais adiante.

Como todo evento do gênero, além de espaço para dança e diversão, esses bailes serviam como uma oportunidade para aproximação entre os jovens, com vistas a namoros e futuros casamentos, porém eram eminentemente "familiares" e havia rígido controle sobre os comportamentos aceitáveis. Logo, embora a cobertura da imprensa exaltasse a beleza das mulheres ali presentes e evocasse um clima de maior descontração nos costumes - típico da mitologia do baile de Carnaval, como analisou Queiroz (1992) -, eles estavam muito longe da permissividade apresentada por aqueles promovidos pelas

${ }^{26}$ Cf. Pfalz (2009): "Os cronistas do século XVII descreveram isto como uma dança distinta, graciosa usada à abertura e encerramento de apresentações. A dança tenta imitar a conversação elegante, que é alcançada por gestos e acompanhada por passos vivos. (...) No centro da moda cosmopolita, em Paris, ao término do século XVIII, a dança foi mudada artisticamente por mestres de balé do período e recebeu o nome ' $\mathrm{La}$ Polonaise'. Assim foi se tornando mundialmente conhecida e usada para abrir e encerrar festas."

${ }^{27}$ Sobre as músicas dos bailes carnavalescos no período, ver: Eneida (1958) e Queiroz (1992). 
principais sociedades carnavalescas do Rio de Janeiro, nos quais havia a participação de muitas prostitutas e amantes.

Os bailes de salão tinham a sua versão "popular", chamada de "público" porque o critério básico para ter acesso era pagar o ingresso, o que produzia a convivência entre diferentes perfis sociais. Tais festas eram realizadas quase sempre por empresários, em espaços fechados, como teatros e hotéis. Em Pelotas, o Teatro Sete de Abril era o local por excelência dessas festas. Alugado, ele se transformava no salão Olimpo, prática iniciada no século XIX e ainda mantida nos anos 1910. Apesar de ocorrer em um espaço bastante conhecido dos pelotenses - ele foi inaugurado em 1831 -, tais eventos preocupavam a imprensa (que os noticiava, mas com alertas quanto ao tipo e ao comportamento dos frequentadores) e a polícia, que buscava desarmar os presentes ou reforçar o efetivo.

Assim, os bailes não se distinguiam radicalmente daqueles realizados em outros períodos do ano: não havia diferenças de público participante, de ritmos e de músicas executadas, de danças realizadas, de trajes utilizados ou de regras de condutas esperadas. $\mathrm{O}$ fato de predominar a fantasia ou a máscara poderia distinguir o baile carnavalesco, mas não de modo definitivo, pois, como indicado, elas também eram utilizadas em outros eventos dançantes realizados ao longo do ano.

\section{Mascarado}

O folião também poderia participar de grupos carnavalescos que comemoram nas ruas. $\mathrm{O}$ melhor exemplo de um festejo refinado e elegante é o já referenciado bloco de salão que, quando estava a caminho do clube, aproveitava o deslocamento para brincar pela cidade. Conforme Ferreira (2004), eles são reminiscências dos passeios que as sociedades carnavalescas cariocas faziam de suas sedes até os teatros, onde participavam de bailes de máscaras. A chegada dos sócios dessas entidades, previamente acordada com os promotores, era uma das atrações do evento, pois implicava o ingresso de um número significativo de foliões e envolvia algum tipo de divertimento específico, como discursos e apresentações musicais. Em Pelotas, registra-se a permanência do costume em 1896, quando o Clube Democrático anunciou que faria passeio burlesco antes da entrada triunfal no baile pré-carnavalesco que a Sociedade Terpsychore realizaria na Biblioteca Pública (DIÁRIO POPULAR, 14 e 17 jan. 1896). Nos anos 1910 esta modalidade já se perdeu, pois os clubes carnavalescos promovem seus próprios bailes. 
Outra modalidade era participar de grupos de assalto. Eles não apresentam nenhuma característica de imprevisibilidade ou animosidade, como o nome pode sugerir. Eram festas realizadas em residências particulares, que seguiam o seguinte roteiro: um grupo de jovens (fantasiados ou mascarados) chegava à casa "de surpresa", fazia uma saudação e oferecia, por meio de seu orador, flores ou outra lembrança à família que estava sendo invadida. O dono agradecia o discurso, entregava a residência aos "assaltantes" e, logo após, iniciavam-se as danças. Pode ser que o uso original do termo indique a prática, adotada ainda no século XIX, de as residências serem invadidas por amigos e parentes dos moradores, cuja visita não era prevista e/ou desejada, com vistas a promover grandes batalhas d'água. Contudo, se esse caráter existiu em alguma oportunidade, perdeu-se no tempo.

Ressalva-se que nos anos 1910, espremido em um calendário lotado de evento, o costume perdia força em benefício dos bailes de salão ou das festividades de rua, como o préstito. $\mathrm{O}$ mesmo não ocorria em outras cidades: os trabalhos de Barbosa (2007, cap. 3), Pedreira (2004, p. 52-53) e Martins (2000, p. 102-103) mostram, respectivamente, a vitalidade do costume em Fortaleza, entre o final dos anos 1920 e o início dos 1930; em Natal, no final da década de 1920; e em São Luis do Maranhão, até pelo menos os anos 1950. Por fim, cabe registrar que o termo "assalto" continuou a ser utilizado por muito tempo para indicar um tipo de comemoração carnavalesca, mas não mais como sinônimo de festas em casas de particulares, e sim de visitas de grupos organizados de foliões de uma entidade à sede de outra, como registra Germano (1999) para o caso de Porto Alegre nos anos 1930 e 1940.

O folião também poderia realizar passeio burlesco de modo solitário. Para os representantes da elite, antigamente esta era uma oportunidade para exibir a faustuosa fantasia e/ou a refinada máscara, cuja inspiração remetia às cortes europeias. Como explica Araujo (1996, p. 249), "a mascarada, tal como a idealizavam seus propagandistas e fiéis defensores, deveria ser luxuosa, ter muito brilho, expressar o cuidado e o esmero com que fora planejada e confeccionada, bem como demonstrar o quanto custou ao bolso daquele que a exibia ou a patrocinava."

O passeio costumava ser realizado mais a cavalo ou de carro do que a pé, como forma de manter a distinção e de não ficar tão à mercê dos populares. Cunha (2001, p. 26) anota que, no caso do Rio de Janeiro, no século XIX, "as máscaras podiam esconder a identidade individual, mas não faziam o mesmo com o status social. Mascarados a cavalo ostentavam seu prestígio olhando de cima aqueles que, a pé, praticavam 
uma brincadeira generalizada sob múltiplos disfarces (...).” Em 1876, a imprensa local lamentou:

o que não podemos deixar passar sem reparo e sem censura é a maneira por que os máscaras em geral foram tratados pelos entrudistas. (...) Aqui, a prevalecer o costume teremos apenas as burlescas figuras carnavalescas, porque ninguém quererá se expor uma roupa de custo às violências do Entrudo (CORREIO MERCANTIL, 02 mar. 1876, p. 1).

Em 1891, 15 anos depois, a confirmar a previsão, foi registrado que

o máscara fidalgo, da alta elite, de finíssimos borzeguins e rico manto constelado de canutilhos, pedrarias e lantejoulas (...) este não apareceu ou por intuição judiciosa de que malbarataria tempo e dinheiro, ou porque receia encarvoar-se ao contato de lamarenta e maltrapilha mascarada (...) (DIÁRIO POPULAR, 12 jan. 1891, p. 1).

Desse modo, nos anos 1910, membros da elite raramente passeavam sozinhos ricamente mascarados ou fantasiados, pois havia novas opções de comemoração, como o corso e o préstito, nas quais, segundo esta ótica, eles estavam mais protegidos, pois não precisavam conviver com as tais "burlescas figuras carnavalescas" ou "encarvoar-se" como anunciava a imprensa, ou seja, com aqueles que perambulavam a apresentar vestimenta e comportamento tão vulgares e perigosos que denunciavam seus níveis sociais e cor da pele.

Isto está longe de significar o desaparecimento dessa tradição, pois fantasiar-se ou mascarar-se e sair em desfile solitário era um costume que vinha sendo adotado também pelos mais pobres, ainda que a partir de versões simplificadas ou improvisadas daqueles trajes utilizados pela elite ou que incorporavam temáticas estranhas ao universo burguês europeizado. Araújo (1996) afirma que, entre os populares, mascararse era um hábito mais antigo do que entre a elite, o que Simson (1984, p. 171) confirma. A partir dos anos 1850 , como em Recife e no Rio de Janeiro, a elite passou a mascarar-se também nas ruas - ou seja, não somente no ambiente protegido dos salões, no qual já era prática corrente -, o que exigiu adaptar este costume ao seu imaginário, pois, cf. Araújo (1996, p. 188), "mascarar-se pelo Carnaval deixava de ser coisa de preto e costume selvagem ou algo vinculado ao passado colonial para transformar-se em sinal de civilidade, polidez, bom gosto e luxo". 
Logo, os mais pobres mantiveram o hábito foi depois que a elite passou a evitar praticá-lo nas ruas, a tal ponto de, no século XX, ter se tornado sinônimo de uma festa sem requinte e inadequada ao modelo do "Grande Carnaval". ${ }^{28}$ Segundo Araújo (Idem, p. 190), a reviver práticas carnavalescas medievais, o que o tornava atraente para o gosto popular era a possibilidade de troçar, injuriar, criticar e lançar ditos picantes a desconhecidos, inimigos, rivais ou mesmo amigos, e permanecer no anonimato e na impunidade.

\section{Eventos pré-carnavalescos}

No período que antecedia à folia - e como parte da mobilização para a festa -, era possível engajar-se em uma série de eventos. A começar pelos passeios burlescos, realizados por fantasiados ou não, acompanhados por bandas de música. Tais passeios se pareciam muitos com aqueles promovidos durante os dias de carnaval e, invariavelmente, envolviam a visita aos cafés e às redações dos jornais.

Também era possível participar da recepção ao Rei Momo comemoração criada pelo Clube Diamantinos, em 1907 - e que constava de um passeio burlesco, realizado nos primeiros dias do ano, ocasião em que Momo instalava-se na sede do clube para comandar a folia. Esta modalidade tinha todos os elementos dos demais passeios, acrescida de algumas peculiaridades: a encarnação de $\mathrm{Momo}^{29}$ realizada por um sócio, que inclusive fazia pronunciamentos bestialógicos ao povo de Pelotas; a representação dos papéis femininos, como os da esposa e da filha, por homens travestidos; a utilização de um carro alegórico para recepcionar o convidado (e que seria depois incorporado ao préstito).

Havia, ainda, a possibilidade de acompanhar as solenidades de coração das rainhas dos clubes, realizadas em teatros. Essas soberanas eram jovens de 15-17 anos, filhas de sócios importantes no âmbito da entidade ou da sociedade como um todo, as quais eram "cultuadas" pelos "súditos": tinham destaque no baile (comandavam a polonaise e ocupavam um trono), no préstito (desfilavam em carro próprio, ricamente decorado, com direito a guarda honra, pajem e corte), bem

${ }^{28}$ Cunha (2001) constrói, a partir do caso do Rio de Janeiro, um diversificado catálogo dessas representações, como: diabinho, morcego, pricês, dominós, pierrôs, velho, além de reprodução do rosto de personalidades então em evidência e a brincadeira do "você me conhece?". Ver também Eneida (1958).

${ }^{29}$ É importante evidenciar que o costume foi desenvolvido antes do advento da encarnação do Rei Momo, o que ocorreu no Rio de Janeiro na década de 1930 e de onde se espalhou pelo país. 
como recebiam uma série de homenagens ao longo do ano, a começar pela cerimônia de coroação. Esta principiava por um cortejo de gala, cujo roteiro incluía recepcionar a jovem em sua casa e levá-la até o local do evento. A coroação propriamente dita era antecipada por atividades artísticas que extrapolavam em muito o campo carnavalesco, tais como: balé, canto lírico e operetas. Alguns números envolviam ritmos mais animados, também presentes nos bailes, como: maxixes, tangos brasileiros e modinhas.

Por fim, apresentações artísticas semelhantes, assim como exposições e quermesses, eram realizadas pelos clubes no segundo semestre, com vistas a arrecadar fundos para a construção dos carros alegóricos e/ou pagar dívidas da folia precedente.

\section{Conclusão}

O propósito do texto foi apresentar as diferentes opções de comemoração que compunham o elenco do "Grande Carnaval" em Pelotas, nos anos 1910, e, desse modo, demonstrar que, apesar de realizada por e para os estratos mais altos da sociedade, era uma festa diversificada. O carnaval se expressava pelo préstito, pelo baile de salão, pelo corso, pelos mascarados solitários ou em bloco, por uma série de eventos preparatórios, todos caracterizados pelo alto custo associado à sua realização, o que colaborava para a distinção social.

Logo, a folia se transformava em uma multiplicidade de eventos, reunidos sob uma única denominação, e que permitia à elite construir a sua própria festa. Contudo, e de modo algo paradoxal, a imagem que surge em uma dimensão mais específica revela outro cenário: modos de comemorar marcados por variações intensas, a indicar a existência de diferentes carnavais, assim como que nesse período as barreiras sociais não estivessem abolidas, os preconceitos superados e as distinções comportamentais suspensas, ou seja, estava-se muito longe de uma harmonia social.

\section{Referências}

ARAÚJO, Patrícia Vargas Lopes de. Folganças populares: festejos de Entrudo e Carnaval em Minas Gerais no século XIX. São Paulo/Belo Horizonte: Annablume/ UFMG, 2008. 186p.

ARAÚJO, Rita de Cássia Barbosa de. Festas: máscaras do tempo: Entrudo, mascaradas e frevo no Carnaval do Recife. Recife: Fundação de Cultura Cidade do Recife, 1996. $423 \mathrm{p}$. 
BANDEIRA JÚNIOR. História do carnaval santista. Santos: A Tribuna, 1974. 102p.

BARBOSA, Carlos Henrique Moura. A cidade das máscaras: carnavais na Fortaleza das décadas de 1920 e 1930. 157p. Dissertação (Mestrado em História Social) - UFCE, Fortaleza, 2007.

BARRETO, Alvaro. Dias de Folia: o carnaval pelotense de 1890 a 1937. Pelotas: Educat, 2003. 156p.

BARRETO, Alvaro. Clube Brilhante 80 anos de História. Pelotas: Clube Brilhante, 1991. 143p.

BARRETO, Alvaro. A Representação de Pelotas na novela "Os Fios Telefônicos". In: GILL, Lorena Almeida / LONER, Beatriz Ana / MAGALHÃES, Mário Osório (Org.). Horizontes Urbanos. Pelotas: Armazém Literário, 2004, p. 7-41.

CORREIO MERCANTIL. Pelotas. 02 mar. 1876.

CUNHA, Maria Clementina Pereira. Ecos da folia: uma história social do carnaval carioca entre 1880 e 1920. São Paulo: Companhia das Letras, 2001. 396p.

DAMASCENO, Athos. O Carnaval porto-alegrense no século XIX. Porto Alegre: Globo, 1970. 125p.

DIÁRIO POPULAR. Pelotas. 12 jan. 1891; 02 mar. 1895; 05 mar. 1895; 14 jan. 1896; 17 jan. 1896; 18 fev. 1896; 27 fev. 1906; 05 fev. 1913.

EFEGÊ, Jota [João Ferreira Gomes]. Figuras e coisas do Carnaval carioca. Rio de Janeiro: MEC-Funarte, 1982. 326p.

ENEIDA [Eneida de Moraes]. História do Carnaval Carioca. Rio de Janeiro: Civilização Brasileira, 1958. 315p.

FERREIRA, Felipe. O Livro de Ouro do Carnaval brasileiro. Rio de Janeiro: Ediouro, 2004. 421p.

FERREIRA, Felipe. Inventando carnavais. Rio de Janeiro: UFRJ, 2005. 358p.

FERREIRA, Felipe. O Triunfal passeio do "Congresso das Summidades Carnavalescas" e a fundação do carnaval moderno no Brasil. Terceira Margem. Rio de Janeiro, n. 14, p. 11-26, jan./jun. 2006.

FERREIRA, Felipe. Um Carnaval à francesa: a construção da folia na cidade de Nice. In: CAVALCANTI, Maria Laura / GONÇALVES, Renata (Org.). Carnaval em múltiplos planos. Rio de Janeiro: Aeroplano, 2009. Cap. 1, p. 15-34.

FLORES, Moacyr. Do entrudo ao carnaval. Estudos Ibero-Americanos. Porto Alegre: Edipucrs, v. XXII, n. 1, p. 149-161, jun. 1999.

FUNDAÇÃO DE ECONOMIA E ESTATÍSTICA. De Província de São Pedro a Estado do Rio Grande do Sul. Porto Alegre, 1986. 330p.

GERMANO, Iris Graciela. Rio Grande do Sul, Brasil e Etiópia: os negros e o carnaval de Porto Alegre nas décadas de 1930 e 40. 275p. Dissertação (História) - UFRGS, Porto Alegre, 1999.

GUIMARÃES, Vicente Falchi. Fundação e outras histórias do Clube Carnavalesco Diamantinos. 26 p. Monografia (Licenciatura em História) - UFPel, Pelotas, 2002.

LAZZARI, Alexandre. Coisas para o povo não fazer: carnaval em Porto Alegre (18701915). Campinas: Unicamp, 2001. 247p. 
LONER, Beatriz Ana. Pelotas se diverte: clubes recreativos e culturais do século XIX. História em Revista. Pelotas, n. 8, p. 37-68, dez. 2002.

MAGALHÃES, Mário Osório. Opulência e cultura na Província de São Pedro do Rio Grande do Sul - um estudo sobre a história de Pelotas (1860-1890). Pelotas: UFPel, 1993. 312p.

MAGALHÃES, Mário Osório. Pelotas toda prosa. Pelotas: Armazém Literário, 2002. v. 2. 307p.

MARTINS, Ananias. Carnaval de São Luís, diversidade e tradição. São Luis: Sanluiz, 2000. 148p.

MELO, Fernando. Os fios telefônicos. Pelotas: UFPel, 1996. 146p.

MÜLLER, Dalila. "Feliz a população que tantas diversões e comodidades goza": espaços de sociabilidade em Pelotas (1840-1870). 340p. Tese (Doutorado em História) - Unisinos, São Leopoldo, 2010.

QUEIROZ, Maria Isaura Pereira de. Carnaval brasileiro: o vivido e o mito. São Paulo: Brasiliense, 1992. 239p.

PEDREIRA, Flávia de Sá. Chiclete eu misturo com banana: carnaval e cotidiano de guerra em Natal 1920-1945. 267p. Tese (Doutorado em História) - Unicamp, Campinas, 2004.

PEREIRA, Cristiana Schettini. Os Senhores da alegria: a presença das mulheres nas grandes sociedades carnavalescas cariocas em fins do século XIX. In: CUNHA, Maria Clementina Pereira (Org.). Carnavais e outras f(r)estas. Campinas: Unicamp, 2002. Cap. 9, p. 311-339.

PEREIRA, Leonardo Affonso de Miranda. O Carnaval das letras: literatura e folia no Rio de Janeiro do século XIX. 2. ed. rev. Campinas: Unicamp, 2004. 318p.

PFALZ, Rheinland. Danças polonesas. 2009. Disponível em: $<$ http://portal.rheinland. com.br/dancas-folcloricas/polonesas/17-danca-polonesa.htm>I. Acesso em: $12 \mathrm{abr}$. 2011.

PICCOLI, João Carlos Jacottet. Clube Diamantinos: 90 anos de história. Pelotas: Clube Diamantinos, 1996. 92p.

SIMSON, Olga Rodrigues von. A Burguesia se diverte no reinado de Momo: sessenta anos de evolução do carnaval na cidade de São Paulo (1855-1915). 283p. Dissertação (Mestrado em Ciências Sociais) - USP, São Paulo, 1984.

SIMSON, Olga Rodrigues von. Brancos e negros no Carnaval popular paulistano (19141988). 245p. Tese (Doutorado em Antropologia Social) - USP, São Paulo, 1989.

VALENÇA, Rachel. Carnaval: para tudo se acabar na quarta-feira. Rio de Janeiro: Relume Dumará, 1996. 98p. 